\title{
UNIWERSYTETY A KULTUROWA JEDNOŚĆ EUROPY
}

Od nas samych zależy to, czym owa zjednoczona Europa stanie się dla nas i czym my dla niej będziemy. Czy zamieszkamy we wspólnym domu ojczyzn, czy też staniemy się lokatorami przedmieścia jakiejś gigantycznej megapolis. Warunkiem pełnoprawnego bycia w Europie jest silne doświadczenie tożsamości i podmiotowości - tak kulturowej, jak obywatelskiej. Jeśli w potężnym organizmie politycznym przyszłości mamy zachować miejsce, do którego aspirujemy, to musimy stać się świadomą siebie częścią organizmu, musimy już teraz rozwijać struktury społeczeństwa obywatelskiego'.

Tymczasem daje się zauważyć coraz większy zanik poczucia obywatelskiej odpowiedzialności za własny los i za los państwa pojętego

1 Pytanie, które w tym miejscu nasuwa się nieuchronnie, dotyczy możliwości osiągnięcia - przez globalizację - stanu pewnej stagnacji i uniformizmowi. Wszystko będzie ujednolicone i oczywiste, zdalnie sterowane przez organizacje centralne. Na płaszczyźnie politycznej, gospodarczej i kulturalnej nastąpi tak ścisłe powiązanie interesów, że wzajemnie będą się one przenikały. Porządek partykularnych interesów narodowych zostanie zastąpiony „wspólnotą interesów”. Procesowi temu będzie towarzyszyć osłabienie pozycji państwa narodowego. Interesy nie będą już wyznaczone granicami jakiegoś narodu, bo te przybiorą charakter na wskroś prywatny. Będzie im służył wolny handel, wymienialność walut, swobodny dostęp do sektora bankowego. W miejsce suwerennych państw powstanie cała klasa ponadnarodowych instytucji, począwszy od międzynarodowych banków aż po wielonarodowe prywatne korporacje. Por. P. G ó r a $1 \mathrm{c}$ z y k, Mundializacja-rozwój czy dekadencja?, „Communio”, 21(2002) nr 124/4, s. 31-32. 
jako dobro wspólne. I ta tendencja może się okazać śmiertelnym niebezpieczeństwem, gdy jako społeczeństwo obojętnych, biernych jednostek staniemy się częścią zjednoczonej Europy ${ }^{2}$.

Co do niej wówczas wniesiemy prócz nieodpartej chęci konsumowania dobrobytu i bezpieczeństwa? W jaki sposób będziemy chcieli wywierać wpływ na to, co się z nami stanie, jeżeli dzisiaj wykazujemy tak powszechną obojętność na sprawy publiczne? I przed jakim zadaniem jako wyzwaniem stają uniwersytety w kontekście kulturowej jedności Europy?

\section{NIEBEZPIECZEŃSTWO POSIADANIA}

Mówimy o jedności i pojednaniu w rodzinie, w organizacjach, w państwach, w Europie, w świecie. Najczęściej sprowadzamy treść pojęć jedności i pojednania do ekonomicznych i politycznych wymiarów. Ekonomiczne pojednanie jednostek, grup społecznych czy państw dokonuje się tutaj w imię zbieżnego interesu, który wszyscy utożsamiają $\mathrm{z}$ optymalnym posiadaniem określonego przedmiotu. Posiadanie określa ich działanie, czyli wytwarzanie przedmiotów, ono też w konsekwencji określa bycie posiadających zamieniając je w pozór bycia sobą. Posiadanie, pełniące rolę zadanej jedności, narzuca podzielonemu światu porządek matematycznej formuły podatny na wolę silniejszego ${ }^{3}$.

2 Zwykła obserwacja pozwala stwierdzić, że na świecie, także w Europie, szybko rośnie bogactwo, ale też marginalizacja i ubóstwo, rodząc przemoc w społeczeństwie, na ulicy, w szkole. Zjawisko to wzmacnia wszędzie silnych, a jeszcze bardziej osłabia słabych. Mimo dość wysokiej stopy wzrostu w krajach rozwijających się różnice w średnich dochodach na osobę narastają i nic nie wskazuje na możliwość odwrócenia tej tendencji. Logika przedsiębiorstw - nastawionych jedynie na zysk - redukuje niewątpliwie człowieka do roli narzędzia. Rozszerza się totalitaryzm zysku i ekonomii, pogłębia się tym samym alienacja człowieka. Czy w tak pojętej mundializacji znajdzie się miejsce na etykę?

${ }^{3}$ Co będzie miał do powiedzenia zwyczajny obywatel tej „cywilizacji planetarnej”? Wszystko będzie oceniane według miary możliwego zysku, również kraje i ludzie. Jesteśmy zresztą tego świadomi, kiedy się mówi i czyta o przygotowaniu naszego kraju do wejścia do Unii Europejskiej. Dobry jest taki kraj, gdzie zysk 
Należy ze smutkiem stwierdzić, że wraz ze społeczeństwem uległy także zasadzie posiadania uniwersytety - także w Europie. Zasada posiadania bowiem przeniknąwszy istotę uniwersytetów, tzn. ich badawcze oraz dydaktyczne działanie, skierowała całą ich uwagę w kierunku szukania narzędzi-formuł i narzędzi-specjalistów, narzędzi, które by pozwalały bardziej i więcej posiadać.

Uniwersytety zachodnie nie były kolebką naukowej mentalności posiadania. Przejęły ją z zewnątrz. Na początku były one ośrodkami kultury; dopiero potem stopniowo przekształcały się w zakłady produkujące wiedzę pojmowaną jako instrument dominowania nad światem ${ }^{4}$. Urzeczone skutecznością nauki dawały się jej całkowicie uwieść: uniwersytety dostosowały się do technicznej cywilizacji.

Z kolei silni zmusili je, by działały już nie przez własną istotę rodzinna universitas professorum et studentium wspólnie przebywająca w zdziwieniu wobec prawdy, której poznawanie było zarazem wychowywaniem (się) - ale przez zewnętrzną, obcą wolę. Kategoria mieć, przeniknąwszy ducha uniwersytetów, zrobiła z nich zakłady usługowe, w których profesorowie zaczęli tworzyć dla silnych coraz doskonalsze narzędzia opanowywania świata (praca badawcza) oraz produkować coraz sprawniejszych konkwistadorów nie liczących się ani z przyrodą, naturą i człowiekiem (praca dydaktyczna).

$Z$ uniwersytetów wychodzą ludzie stanowiący tzw. elitę, która ma rządzić światem. Nie są oni zdolni widzieć świata w jego prawdzie,

jest łatwy i możliwy szybko do osiągnięcia. Dobre jest takie państwo, które zapewnia stabilność waluty, porządek społeczny i które inwestuje w wykształcenie i wyposażenie; dobry jest taki pracownik, który dużo pracuje, ma bardzo wysokie kwalifikacje i małe wymagania odnośnie do płacy. Czy w tym wszystkim myśli się o konkretnym człowieku, o dobru wspólnym, pojętym jako zespół warunków życia, dzięki którym każdy człowiek może osiągnąć własną doskonałość?

${ }^{4}$ Współczesna jednocząca się Europa potrzebuje idei przewodnich, które pochodzą ze wspólnych przekonań, postaw i tradycji. Kościół nie tylko ich dostarcza, lecz stwarza motywację do ich zachowania. Podstawowe prawa bowiem, takie jak: sprawiedliwość, wolność, pokój, równość, solidarność i godność człowieka, bez zakotwiczenia w obszarze wiary zawieszone są niejako w próżni, a co gorsza, sa także podatne na nadużycia ideologiczne. Por. K. L e h m a n n, Glauben bezeugen, Gesellschaft gestalten. Reflexionen und Positionen, Freiburg-Basel-Wien 1993, s. 38. 
lecz jedynie poprzez swoje oraz silnych interesy i sukcesy. Jak więc mogą mieć szacunek dla niego? Niezdolni widzieć całość, a tylko coraz bardziej wyabstrahowane fragmenty (specjalizacja), widzą świat fałszywie, odbierają mu sens i wartość. Zamiera w nich sumienie, ponieważ zamiera w nich umysł prawdy.

Uniwersytety przestały być sumieniem społeczeństw, bo przestało w nich chodzić o prawdę, którą trzeba zarówno poznać jak i czynić. W konsekwencji w uniwersytetach przestało chodzić o sprawiedliwość (czynienie prawdy w miłości) - zadowalają się one mniemaniami z platońskiej jaskini. Przestały pytać o człowieka, pytają jedynie o przedmioty - o cienie rzeczy i ludzi, którymi można posługiwać się dowoli. W ten sposób uniwersytety utraciły swój ethos, stały się „,bezdomne”, a raczej w nich stali się „bezdomni” professores et studentes. Goniąc za sukcesem oddają się na służbę tym, od których on zależy ${ }^{5}$.

Uniwersytety zaakceptowawszy prymat posiadania i techniki nad byciem i poznaniem utraciły wiarygodność. Ludzie zwracają się dziś do uniwersytetów, aby się nimi posługiwać, a nie aby im wierzyć. Umieją one bowiem bezbłędnie liczyć; ich formuły równań pozwalają trzymać w garści przedmiotowy świat. Cóż z tego jednak, skoro ich badawczej i dydaktycznej pracy nie przenika idea prawdy, rodząca postawę przymierza względem każdego bytu, lecz idea skutecznej konstrukcji z przedmiotów i skutecznej reprodukcji sprawnych osobników, tak do siebie podobnych, że nie czujących, iż są częściami

5 Podejmując krytykę rozbudzonych postaw konsumpcyjnych, Kościół przeciwdziała ich przerodzeniu się w niepohamowany konsumpcjonizm. Odsłania na nowo przysłonięty świat wartości wyższych. Stawia człowieka na pierwszym miejscu, przed wszelkimi technologiami i procesami ekonomicznymi. Troszcząc się o całego człowieka oraz o jego osobową tożsamość, odrzuca wszelkie próby redukowania go do roli konsumenta lub wytwórcy dóbr konsumpcyjnych. Staje też zawsze w obronie społecznie poszkodowanych, również w odniesieniu do regionów gospodarczo zacofanych i zaniedbanych. Por. J. P i e c u c h, Kościót w Europie zjawisk globalizacyjnych i integrystycznych, w: Europa. Zadanie chrześcijańskie, Warszawa 1998, s. 319. 
siebie, czujących natomiast, że są wyłącznie częściami zamiennymi ${ }^{6}$. Nic tak nie dzieli, jak nadzieja położona w sukcesie, jak sukces, kiedy jest naczelnym zadaniem, choćby dla jednego człowieka czy jednego społeczeństwa.

\section{NOWA NADZIEJA}

Czy uniwersytety mogą stać się dzisiaj miejscem, w którym odrodziłaby się jedność Europy? jedność świata? Jakie warunki musiałyby one spełnić, aby stać się na nowo ethosem dla jednostek i dla narodów? ${ }^{7}$

Jedność Europy i świata spełnia się w pojednaniu się człowieka z człowiekiem, człowieka z całym światem. Pojednanie to zaczyna się od pojednania się człowieka ze samym sobą. Żeby więc uniwersytety

6 W tym kontekście bardzo tramę jest ostrzeżenie Jana Pawła II: „Dla zjednoczenia Europy nie ma alternatywy, zaś dla tej jedności platformą pozostaje nienaruszalna godność osoby ludzkiej, związana z europejską kulturą życia, która nie tylko zwraca uwagę na to, że Europie dobrze się wiodło pod względem gospodarczym i finansowym, lecz i na to, że jest kontynentem zbudowanym na wartościach, które kiedyś doprowadziły do jej wielkości”. Biuletyn Katolickiej Agencji Informacyjnej, nr 69 z 25 marca 1997, s. 7.

7 Ocena jakości kultury europejskiej jest sprawą fundamentalną dla faktycznej jedności Europy. Nie ulega wątpliwości, że jedynie kultura oparta na wartościach chrześcijańskich godna jest miana europejskiej. Ujmując problem nieco inaczej można powiedzieć, że fundamentem Europy jest oparta na chrześcijańskiej aksjologii wizja osoby ludzkiej oraz wynikające z niej wartości etyczne. To właśnie stąd „,pochodziło wiele pobudek do zachowań i przedsięwzięć, jakie - przynajmniej później - pojawiły się poza Kościołem, a niekiedy występowały także przeciw niemu. Wystarczy wspomnieć o humanizmie, o roli techniki, znaczeniu nauki i odkryć, jak ten o randze praw człowieka. Podobnie ma się sprawa z konkretnymi przejawami humanitaryzmu Europy, widocznymi jeszcze w ruchach inspirowanych przez chrześcijaństwo, np. w dziełach dobroczynnych, które jednak oddaliły się od wiary chrześcijańskiej lub wręcz wyobcowały się z niej. Dziś zapomina się często o tym pochodzeniu, zaprzecza się mu; bywa ono także zniekształcane". K. L e h m a n n, Nowa Europa - fikcje $i$ wizje. Doświadczenia $i$ wyzwania z perspektywy Kościoła. Uroczysty wykład z okazji nadania godności doktora ,honoris causa”, 28.IV. 1997, (mps), s. 2. 
mogły przyczynić się do zjednoczenia Europy i świata, muszą na nowo zacząć pytać o człowieka, o jego istotę, o jego tożsamość tak, aby widzieć ją zarówno wiedzą jak i nadzieją ${ }^{8}$.

Pytać o tożsamość ludzkiej istoty znaczy pytać o Człowieka, który dopiero rodzi się w każdym z nas i z którym utożsamiamy się. Pracę dla narodzin Człowieka w ludziach nazywam kulturą, czyli uprawianiem człowieka dla Człowieka. Właśnie w Nim, odnajdywanym we wszystkich, spełnia się pojednanie wszystkich. Jeśli zatem mówimy o kulturowej jedności Europy, to przede wszystkim mówimy o pojednaniu Europejczyków w europejskim wyrażaniu i uprawianiu człowieka dla Człowieka. Europejskie wyrażanie i uprawianie człowieka zostało ukształtowane przez fundamentalne sokratejskie i judaistyczne pytanie o ludzka istotę. Europejczyk jako Europejczyk jest sokratejsko i judaistycznie świadomy, że jedność międzyludzka znajduje się w samych ludziach, a nie w takich czy innych strukturach posiadania. Dlatego tak bardzo obcy jest kulturze europejskiej język mówiący o jedności jako o czymś li tylko ekonomiczno-politycznym. Więcej, obcy jest każdej kulturze.

$\mathrm{Z}$ tej perspektywy patrzę na zadania uniwersytetów zachodnich. Nie przyczynią się one do jedności Europy i świata, jeśli nie staną się miejscem kultury, przede wszystkim kultury, a dopiero potem nauki; przede wszystkim miejscem wychowywania człowieka dla Człowieka, a dopiero potem miejscem uczenia zawodu. Taka jest bowiem istota rodzinnej wspólnoty mistrza z uczniem, istota, do której uniwersytety przynależą, a od której odeszły ${ }^{9}$.

8 I dlatego dla Jana Pawła II jest oczywiste, iż Europa nie może porzucić chrześcijaństwa, jak przygodnego towarzysza podróży, który stał się jej obcy, podobnie jak człowiek nie może porzucić podstaw swojego życia i nadziei, nie popadając przy tym w dramatyczny kryzys. Por. J a n P a w e ł II, Kryzys Europy jest kryzysem chrześcijaństwa w Europie. Przemówienie do uczestników V Sympozjum Konferencji Episkopatów Europejskich, „L'Osservatore Romano”, (1982) nr 10, s. 5.

9 Stwierdzenie, iż godna miana europejskiej jest taka kultura, która oparta jest o chrześcijańską wizję człowieka i wynikające stąd wartości etyczne, nie oznacza powrotu do jakiegoś minionego etapu istnienia Europy. Nie może ona jednak nie uwzględniać owego historycznego aspektu. Byłoby to budowanie bez fundamentu, 
Wspólnoty uniwersyteckie powstawały w Średniowieczu jako naturalna odpowiedź na ówczesne stawiane pytania o bycie człowieka. Ich działania badawcze i dydaktyczne ożywiała kategoria bycia, a nie posiadania: w badaniach szukano poznania prawdy nieoddzielonego od czynienia jej; mistrz poznawał razem z uczniem. W ten sposób kształcił go i wprowadzał w świat wspólnej prawdy, w ethos człowieka. Ze stosunku sumienia do prawdy wyrastało twórcze pojednanie mistrza z uczniem, decydujące o jakości uniwersytetu. Tworzyli oni jakby cechową rodzinę dla prawdy tego, co dane, oraz tego, co zadane. In principio uniwersytet był dłużny człowiekowi prawdę, a nie umożliwienie dobrej ekonomicznie kariery. Kto wchodził weń, pod wpływem kategorii posiadania, niszczył w zarodku rodzinny stosunek mistrz - uczeń. Niszczył uprawianie człowieka dla Człowieka, to znaczy niszczył kulturę.

Obcowanie osób odgrywa ogromną kulturotwórczą rolę w życiu wszelkiej społeczności, a tym bardziej w życiu uniwersytetu. Umiejętności zawodowych (cywilizacyjnych) można się wyuczyć z podręczników, ale kultury i otwarcia się na Człowieka - tylko ex auditu. Osobowy stosunek mistrz - uczeń, obok rodziny, jest czymś pierwotnym w społeczeństwie, ale nie czymś już gotowym, lecz domagającym się ustawicznego budowania. Zarówno uniwersytet jak i rodzina są wtedy, kiedy się je buduje. Ustawiczne budowanie uniwersytetu i rodziny sprawia, że wzrastają one w miasto, w narody. Jednoczą je, stając się zasadą ich kulturowej historii oraz kulturowej jedności ${ }^{10}$.

czyli po prostu na niebezpiecznym gruncie. Porzucenie tej tradycji byłoby zdradą kultury europejskiej w samej jej istocie: „Gdyby religijne i chrześcijańskie podłoże tego kontynentu zostało zepchnięte na margines w swojej roli źródła inspiracji etycznej i w swoim wpływie na kształt życia społecznego, wtedy zostałoby zanegowane cale dziedzictwo europejskiej przeszłości, ale także zagrożona zostałaby przyszłość godna Europejczyka”. List Pasterski Episkopatu Polski na Tydzień Powszechnej Modlitwy o Jedność Chrześcijan, 18-25.1.1989, s. 2.

10 Jan Paweł II wspomina o niebezpieczeństwie alienacji człowieka, która polega na odwróceniu relacji środków i celów. Ludzie pozbawiają się w tej sytuacji „możliwości przeżywania w pełni własnego człowieczeństwa”, co łączy się „z utratą 
Jeżeli mówię, że uniwersytet musi dzisiaj na nowo przemyśleć swoją istotę i do mej powrócić, chcę powiedzieć, że musi wypracować odpowiednią koncepcję człowieka. Pytanie o człowieka, będące równocześnie kulturowym pytaniem o Człowieka, musi w uniwersytecie zająć pierwsze miejsce. Cywilizacyjne pytania o przedmioty-narzędzia winny natomiast zejść na drugi plan, co nie znaczy, że na plan nieważny. Pytanie o człowieka a nie pytanie o przedmioty -narzędzia winno kształtować uniwersytet. W pewnym sensie uniwersytet ma być tym pytaniem, aby mógł uczyć rozumieć wytwory człowieka poprzez człowieka, a nie odwrotnie. Nie pojmiemy kultury poprzez rozumienie cywilizacji, ale pojmiemy cywilizację poprzez rozumiejące pojmowanie kultury człowieka, bo kultura nie jest ozdobą cywilizacji, tak jak człowiek nie jest kwiatkiem dolepionym do swoich produktów.

Europejskie uniwersytety mają zatem strzec europejskiego dziedzictwa kulturowego, europejskiego wyrazu prawdy człowieka; mają przyczyniać się do wzrostu tego dziedzictwa, jeżeli Europa nie ma zmarnieć w zniewoleniu przez naukowy totalizm unifikującej, to jest izolującej wszystkich od wszystkich, cywilizacji. Uniwersytety stoją wobec trudnej i pełnej ryzyka wolności. Znajdują się poniekąd w sytuacji Antygony, która, by zostać sobą i dać szansę ocalenia się nawet Kreonowi, musi rzucić na szalę własne życie. Byłoby pięknie, gdyby Kreon potrafił przezwyciężyć siebie i poparł Antygonę wbrew swoim doraźnym interesom. Zazwyczaj jednak dziej się inaczej.

Uniwersytet strzegąc godności człowieka sam staje się godny. Ulegając Kreonowi wystawia się na pogardliwy uśmiech najpierw studentów i samego Kreona, a następnie całego społeczeństwa. Traci wiarygodność, ponieważ traci swoją tożsamość i działa przez obcą sobie siłę. W kulturze widzę wielki akt nadziei człowieka nie zadowalającego się posiadaniem, w uniwersytetach zaś widzę miejsce

autentycznego sensu istnienia”. Człowiek sam dostaje się w „układ stosunków zdeterminowanych przez bezwzględną rywalizację i wyobcowanie, w którym jest on traktowany jedynie jako środek, nie zaś jako cel'. Encyklika Centsimus annus, $\mathrm{nr} 41$. 
budzenia tej nadziei. Gdy jej nie ma, byt ekonomiczny staje się wszystkim. Lecz czymże jest byt ekonomiczny, gdzie się go próbuje osadzić w niebycie?

Na koniec powiedzmy po prostu: człowiek i społeczeństwo czerpią swoją jedność z Chrystusa. Ten, kto nie jest z Nim, rozprasza (Łk 11,23). Tracimy czas szukając jedności „tu” albo „tam”, jeśli wolno sparafrazować słowa Chrystusa (,,jeśliby wam kto powiedział: oto tu jest Mesjasz, albo tam - nie wierzcie, Mt 24,23). Te bowiem przestrzenno-czasowe kategorie są kategoriami ekonomicznymi i politycznymi - są zatem kategoriami posiadania. Tymczasem jedność znajduje się w objawieniu się synów Bożych, na które czekamy (Rz 8,19). Christianitas, mieszcząca się „tu” albo „tam” jest tym, za czym tęsknimy. Przekracza ona konserwatyzm kategorii posiadania. Dana naszej nadziei, christianitas, przekracza wszelkie „tu” i wszelkie „tam”, ponieważ jest jak błyskawica, która zabłyśnie na wschodzie, a świecie aż na zachodzie (Mt 24,23-27).

\section{WIEDZA NAUKOWA W SŁUŻBIE CZLOWIEKA}

Zadaniem uniwersytetu jest naturalnie uczyć, ale w gruncie rzeczy jest on po to, żeby człowiek, który do niego przychodzi, który ma swój własny rozum już nieco rozwinięty i pewien zasób doświadczenia życiowego, nauczył się myśleć sam. Uniwersytet jest po to, żeby wyzwolił ten potencjał umysłowy i potencjał duchowy człowieka, żeby pomógł w jego wyzwoleniu się - ale to wyzwolenie jest aktem własnym, aktem osobowym tego człowieka. Uniwersytet wtedy spełnia swój cel, gdy w określonej wspólnocie ludzi przy pomocy środków o charakterze naukowo-twórczym, naukowo-badawczym prowadzi do tego, że się rozwija człowiek, że się wyzwala jego wszechstronny potencjał duchowy. Potencjał umysłu, woli i serca; formacja całego człowieka.

Uniwersytet to jest jakiś odcinek walki o człowieczeństwo człowieka. Bowiem można wytworzyć serię ludzi wyuczonych, wykształconych, ale problem jest nie w tym; chodzi o to, czy się wyzwoliło ten olbrzymi potencjał duchowy człowieka, przez który człowiek 
urzeczywistnia swoje człowieczeństwo. W świecie współczesnym, w różnych tego świata systemach, wytworzonych nas gruncie różnych ideologii, które zresztą mają dość wspólny korzeń, coraz bardziej będzie oczywiste, że sama tylko produkcja wykształconych, wysoko wyszkolonych, wyspecjalizowanych jednostek nie rozwiązuje zagadnienia. Nie rozwiązuje zagadnienia człowieka. Droga uniwersytetu, droga społeczeństwa ludzkiego, droga narodu i ludzkości, to droga do wyzwalania człowieczeństwa, tego wielkiego potencjału możliwości ducha ludzkiego, umysłu, woli i serca - kształtowanie wielkiego człowieczeństwa, dojrzałego człowieczeństwa.

W przeszłości ideałem Universitas było dążenie do unifikacji wiedzy poprzez próby pogodzenia ze sobą wszystkich elementów prawdy osiągalnych za pośrednictwem nauk przyrodniczych i teologicznych. To, co wynikało z prowadzonych przez człowieka badań, było rozumiane w świetle Objawienia odnajdywanego w Ewangelii. Prawda łaski jest także prawdą natury. Rozwój współczesnej nauki i zdumiewająca skala współczesnych badań naukowych wykluczają oczywiście powstanie jakiejś prostej syntezy dzisiejszej wiedzy. Nie istnieją żadne współczesne wersje tego, co nazywano niegdyś summa, kompendium czy tractatus. Jednak wiele spośród najwybitniejszych umysłów dzisiejszego świata uniwersyteckiego z naciskiem podkreśla konieczność ponownego zdefiniowania na potrzeby naszych czasów pierwotnych pojęć Universitas i humanista, które w nowy sposób - powinny nadal kierować ku niezbędnej integracji wiedzy, tak abyśmy mogli uniknąć pułapek, jakie stwarza zbyt pragmatycznie ukierunkowany profesjonalizm i wzajemnie nie powiązane nadmierne specjalizacje w programach uniwersyteckich. Chodzi o przyszłość kultury naprawdę ludzkiej, otwartej na przyjęcie wartości etycznych i duchowych.

Istnieje wyraźna potrzeba nowego chrześcijańskiego humanizmu oraz nowej wersji wykształcenia w dziedzinie nauk humanistycznych - Kościół katolicki z najwyższym zainteresowaniem śledzi badania i doświadczenia, jakie są podejmowane w związku z tym zagadnieniem. Należy przede wszystkim w sposób realistyczny przyjąć rozwój i przemiany zachodzące we współczesnych uniwersytetach, 
dziś bez porównania liczniejszych niż dawniej i o wiele bardziej złożonych. Kraje dzisiejszego świata są dumne ze swoich uniwersytetów, pozostających instytucjami, aby zastanowić się nad tym szczególnym powołaniem europejskich uczelni, jakim jest stale podtrzymywanie ideałów wolnej oświaty i uniwersalnych wartości, które wnosi do szkolnictwa wyższego tradycja kulturowa, naznaczona chrześcijańskim dziedzictwem.

Minęły już czasy, kiedy uniwersytety Europy jednogłośnie odwoływały się do jednego centralnego autorytetu - do chrześcijaństwa. Nasze społeczeństwa muszą żyć w pluralistycznym kontekście, wymagającym dialogu między wieloma tradycjami duchowymi w nowym dążeniu do harmonii i współpracy. Dla uniwersytetu jako instytucji sprawą zasadniczej wagi pozostaje jednak nieustanne odwoływanie się do umysłowego i duchowego dziedzictwa, które na przestrzeni wieków ukształtowało naszą europejską tożsamość.

Czym jest to dziedzictwo? Są to: godność osoby ludzkiej, świętość życia, podstawowa rola rodziny, wielka waga oświaty, wolność myśli i słowa, swoboda wyznawania własnych przekonań religijnych, prawna ochrona jednostek i grup ludzkich, współpraca wszystkich ludzi na rzecz wspólnego dobra, koncepcja pracy jako udziału w dziele samego Stwórcy, autorytet państwa, które samo rządzi się prawem i rozsądkiem. Wartości te należą do skarbca kultury europejskiej, są klejnotem zrodzonym z wielu myśli, dysput i cierpienia. Stanowią one duchową zdobycz rozsądku i sprawiedliwości, a ta przynosi zaszczyt narodom Europy w ich dążeniu do wprowadzania w bieg czasu ducha chrześcijańskiego braterstwa, jakiego uczy nas Ewangelia.

Uniwersytety powinny być tym szczególnym miejscem, gdzie owe przekonania - sięgające korzeniami świata Greków i Rzymian, a wzbogacone i rozbudowane przez judaistyczną oraz chrześcijańską tradycję - nabierają ciepła i światła. To właśnie w obrębie tej tradycji rozwinęło się wyższe pojęcie osoby ludzkiej, widzianej jako obraz Boga, odkupionej przez Chrystusa i powołanej ku wiecznemu przeznaczeniu, wyposażonej w niezbywalne prawa i odpowiedzialnej za wspólne dobro społeczeństwa. Dzięki teologicznym dysputom 
na temat podwójnej natury Jezusa Chrystusa rozwinęło się pojęcie osoby, która stanowi kamień węgielny zachodniej cywilizacji.

W dzisiejszych czasach rośnie moralne poczucie prawdziwości tej zasady, wspólne ludziom na całym świecie. Wartość i godność jednostki nie zależą od systemów politycznych czy ideologicznych, lecz znajdują podstawy w porządku naturalnym - w obiektywnym porządku wartości. Takie przekonanie doprowadziło do powstania w 1948 roku Deklaracji Praw Człowieka Organizacji Narodów Zjednoczonych; stała się ona kamieniem węgielnym w dziejach ludzkości, a Kościół katolicki bronił jej i rozbudowywał jej treści w oficjalnych dokumentach. Tragiczne wydarzenia ostatniego stulecia pokazały, na jakie zagrożenie i zniszczenie narażone są istoty ludzkie, gdy rządy odmawiają im podstawowego prawa do godności.

Godność osoby ludzkiej można ochronić jedynie wtedy, gdy się uzna, że jest ona nietykalna od chwili poczęcia do śmierci naturalnej. Osoby ludzkiej nie można redukować do statusu środka lub narzędzia w rękach innych ludzki. Społeczeństwo istnieje po to, aby dbać o bezpieczeństwo i godność osoby ludzkiej. Podstawowym prawem, jakiego musi ono bronić, jest zatem prawo do życia. Żadnej osobie ludzkiej nie wolno zniszczyć po to, aby ułatwić Zycie innym. Każdego człowieka trzeba traktować jako ostateczny cel sam w sobie. Jest to podstawowa zasada wszelkiego ludzkiego działania: opieki zdrowotnej, wychowania dzieci, oświaty, środków masowego przekazu. Dopóki społeczeństwo nie uważa osoby ludzkiej na nietykalną, niemożliwe jest sformułowanie spójnego systemu zasad etycznych, jak również stworzenie klimatu moralnego, sprzyjającego ochronie najsłabszych członków rodziny ludzkiej.

W naszym systemie uniwersyteckim zachowało się nauczanie teologii, co stwarza współczesnym ludziom możliwość badania Słowa Bożego i jego znaczenia. Nasza epoka odczuwa wielką potrzebę badań interdyscyplinarnych, które mogłyby wyjść naprzeciw złożonym wyzwaniom, jakie przynosi postęp. Problemy te wpływają na nasz stosunek do spraw życia i śmierci, kształtują poglądy na groźbę, jaką niesie manipulacja genetyczna, na zasięg oświaty i sposób przekazywania wiedzy oraz mądrości młodszemu pokoleniu. 
Wspaniale odkrycia w dziedzinie nauki są z pewnością godne podziwu, równocześnie jednak zdajemy sobie sprawę z destruktywnej potęgi współczesnej techniki, która może zniszczyć ziemię ze wszystkim, co się na niej znajduje. Mobilizacja umysłów i sumień jest zatem palącą potrzebą.

Kościół, przechowując depozyt ewangelicznej prawdy, wskazuje człowiekowi ostateczne cele, z którymi nierozdzielnie wiążą się cele najbliższe i społeczne, kultywowane w uniwersytetach. Z drugiej strony, horyzonty nauk ścisłych i humanistycznych, które otwiera uniwersytet, domagają się zharmonizowania w jednej i jednoczącej wizji, która obejmie całego człowieka i wskaże mu sens jego poszukiwań i prac na ziemi. Dobrze wyraża tę myśl aksjomat św. Ireneusza: Gloria Dei vivens homo, ,żyjący człowiek jest chwałą Bożą, a życie człowieka jest wizją Boga"'11. Bóg pragnie chwały człowieka, człowiek zaś w Bogu znajduje swą chwałę. Nic, co ziemskie, nie jest na jego miarę, nic nie może go zaspokoić. Kościół i uniwersytet zajmują się promocją tego specyficznego życia, które prowadzi człowieka do oglądania Boga. To dlatego Kościół był obecny przy narodzinach pierwszych uniwersytetów i zawsze spoglądał z uznaniem oraz sympatią na uniwersytet jako laboratorium wiedzy i badań służących osobie ludzkiej i społeczeństwu ${ }^{12}$.

\footnotetext{
11 Adv. Haer. IV, $20,7$.

12 Zamienny jest w tym kontekście tekst aktu erekcyjnego Uniwersytetu Krakowskiego wydanego przez Kazimierza Wielkiego z dnia 12 maja 1364 roku: „Niechże więc tam będzie nauk przemożnych perła, aby wydawała mężne dojrzałością rady znakomite, ozdobą cnót świetne i w różnych umiejętnościach biegłe. Niechaj otworzy się orzeźwiające źródło a z jego pełności niech czerpią wszyscy naukami napoić się pragnący. Do tego to miasta Krakowa niechaj zjeżdżają się swobodnie i bezpiecznie wszyscy mieszkańcy nie tylko królestwa naszego i krajów przyległych, ale i inni z różnych części świata, którzy pragną na być tę prześwietną perłę wiedzy”.
} 


\section{Streszczenie}

Cel uniwersytetu - cel wiedzy naukowej nie zawiera się w niej samej, gdyż pozostaje ona w służbie człowieka: człowieka-osoby i całej ludzkości, człowieka pojmowanego jako rodzaj ludzki, odznaczający się cechą jemu tylko właściwą: obecnością ducha i wiedzy, świadomości i woli - oraz zdolnością działania świadomego i wolnego. Nauka nie może twierdzić ani sądzić o sobie, że jest neutralna wobec człowieka: jest bowiem darem pochodzącym z Wysoka i zarazem zdobyczą niestrudzonego ducha, który poszukuje i znajduje, wyjaśnia i porządkuje. Nauka prowadzi do wyzwolenia i wywyższenia człowieka.

\section{Universities and Cultural Unity of Europe Summary}

The goal of a university - the aim of scientific knowledge - is not self-contained, because it remains at the service of man: man as a person and the entire humanity, men conceived as mankind, with a feature proper only to them: the presence of the spirit of knowledge, conscience, and will as well as the ability to act knowingly and freely. Science cannot claim or opine of itself that it is neutral with respect to man: for it is a gift bestowed from Above and also an achievement of a tireless spirit which seeks and finds, explains and orders. Science leads to the liberation and exaltation of man.

\section{Bibliografia:}

Sajdek W. (red.), Czasy katedr - czasy uniwersytetów. Źródta jedności narodów Europy, Lublin 2005.

Markowski M., Pierwowzory uniwersytetów, Olecko 2003.

Sobeczko H.J, Europa uniwersytetów, w: S. Rabiej (red.) Duchowe dziedzictwo Europy, Opole 1998, s. 49-64.

Marek F., Godność, dostojeństwo i postannictwo Uniwersytetu, Opole 1995. Janeczek S., Edukacja oświeceniowa a szkoła tradycyjna. Z dziejów kultury intelektualnej i filozoficznej, Lublin 2008.

Wielgus S., Zachodnia i polska nauka średniowieczna, Płock 2005.

Vetulani A., Poczatki najstarszych wszechnic środkowoeuropejskich, Wrocław 1970. 